\title{
Genetic Diversity of Seven Strawberry mottle virus Isolates in Poland
}

\author{
Mirosława Cieślińska (DD * \\ Department of Plant Pathology, Research Institute of Horticulture, Konstytucji 3 Maja 1/3, 96-100 Skierniewice, Poland \\ (Received on December 31, 2018; Revised on February 15, 2019; Accepted on April 3, 2019)
}

The studies on detection of the Strawberry mottle virus (SMoV) have been conducted in Poland for breeding programme purpose and for producers of strawberry plant material. Leaf samples collected from infected strawberry plants were grafted on Fragaria sp. Indicators which were maintained in greenhouse for further study. Seven Fragaria vesca var. semperflorens 'Alpine' indicators infected by SMoV were used for the study aimed on molecular characterization of virus isolates. Partial RNA2 was amplified from total nucleic acids using the RT-PCR method. The obtained amplicons separately digested with $B f a I$, FauI, HaeIII, HincI, and TaqI enzymes showed different restriction profiles. The nucleotide sequences analysis of RNA2 fragment confirmed the genetic diversity of the $\mathrm{SMoV}$ isolates as their similarity ranged from 94.7 to $100 \%$. Polish isolates shared $75.7-99.2 \%$ identity with sequence of the virus strains from the Czech Republic, the Netherlands, and Canada. Phylogenetic analysis resulted in grouping of the isolates found in Poland together with one of the Czech strain whereas two other from the Czech and the strains from the Netherlands and Canada created the separate cluster.

Keywords : phylogeny, restriction analysis, sequencing, Strawberry mottle virus

Handling Editor : Choi, Seung-Kook

\footnotetext{
*Corresponding author.

Phone) +48 4683452 36, FAX) +48 468333186

E-mail) Miroslawa.Cieslinska@inhort.pl

ORCID

https://orcid.org/0000-0001-6023-9070

(c) This is an Open Access article distributed under the terms of the Creative Commons Attribution Non-Commercial License (http:// creativecommons.org/licenses/by-nc/4.0) which permits unrestricted noncommercial use, distribution, and reproduction in any medium, provided the original work is properly cited.
}

Articles can be freely viewed online at www.ppjonline.org.
Strawberry mottle virus (SMoV), classified in the family Secoviridae, order Picornavirales (Sanfacon et al., 2009; Thompson et al., 2002) is one of the most common viruses on strawberry plantations in Europe. SMoV is transmitted by strawberry aphids Chaetosiphon sp. and Aphis gossypii in a semi-persistent manner (Frazier and Sylvester, 1960). Despite the fact that infected plants usually do not show any characteristic symptoms, severe strains of SMoV may reduce vigor and yield by 20 to $30 \%$ (Mellor and Krczal, 1987). The incidence of SMoV on strawberry plantations has been reported in many countries of Europe, and in Argentina, USA, Canada, New Zealand, and Australia. The studies conducted in Poland so far have been aimed at occurrence and detection of the virus, its impact on the yield of strawberries and reaction of some herbaceous plant species on SMoV infection (Babini et al., 2004; Cieślińska, 2004; Cieślińska and Stankiene, 2004; Cieślińska and Zawadzka, 1991, 1996). Time-consuming and labor-intensive biological indexing used to be applied as the standard for the detection of SMoV until diagnostics techniques based on the detection of pathogen's nucleic acids became an alternative to these tests. The development of new detection methods was possible due to the knowledge of the $\mathrm{SMoV}$ genome (Thompson and Jelkmann, 2003; Thompson et al., 2002, 2003). The positive-sense RNA genome is divided into two segments: RNA1 which encodes polyprotein P1 with domains for a putative RNA helicase, a 3C-like protease and an RNA-dependent RNA polymerase and RNA2 encodes a polyprotein P2 consisting of, among others, movement protein and coat protein (Thompson et al., 2002). The complete sequence of RNA2 is currently available for nine $\mathrm{SMoV}$ isolates found in the Netherlands (Thompson et al., 2002), Canada (Bhagwat et al., 2016), and the Czech Republic (Koloniuk et al., 2018).

The aim of this study was to characterize the molecular properties of the seven $\mathrm{SMoV}$ isolates found in strawberry plants in Poland and to examine their genetic variability based on the sequence of RNA2 fragment.

Seven symptomatic Fragaria vesca var. semperflorens 
'Alpine' indicator plants grafted previously with leaflets of SMoV infected strawberry: Grandarosa', 'Pink Rosa', 'Pegat', 'Markat', 'Granat' (isolates: Granda-1108, Pink1108, Pegat-1108, Markat-1108, and Granat-1108 isolates, respectively) and two unknown cultivars (isolates: karkas-1108 and Unkn-1108 isolates) were used as the plant material in this study. Mild to severe mottling and chlorotic spots symptoms were observed on the indicators' leaves. All of the infected plants were maintained in greenhouse in virus collection of the Horticulture Institute in Skierniewice, Poland.

The silica capture method described by Boom et al. (1990) with adaptations by Malinowski (1997) was used for extraction of the nucleic acids from the symptomatic leaves of $F$. vesca.

One-tube reverse transcription-polymerase chain reaction (RT-PCR) was conducted to amplify the RNA2 fragment of the virus using primers $2 \mathrm{SMoV} 1108-\mathrm{F}$ (5' GCGGACGCTGTTGCCACTT 3') and 2SMoV2386-R (5' TCCGCCGCTCCCACTGATT 3'). This primer pair was designed during this study based on RNA2 sequence of Ontario isolate from Canada (GenBank accession number: KU177219). RT-PCR assay was performed with a thermocycler PTC-200 (MJ Research, Inc., USA), and $7 \mu 1$ of the amplification products were resolved by electrophoresis in $1.2 \%$ agarose gel in $0.5 \mathrm{X}$ TBE buffer, stained in ethidium bromide and visualized on UV transilluminator (Syngen, Cambridge, England). The molecular weight of the PCR products was estimated by comparison with $100 \mathrm{bp}$ DNA ladder (ThermoFisher Scientific). cDNA from a leaf sample of an healthy $F$. vesca 'Alpine' and from $\mathrm{SMoV}$ infected strawberry were included as the negative and positive controls, respectively.

Five $\mu 1$ of the RT-PCR products were separately digested with by BfaI, FauI, HaeIII, HincI and TaqI enzymes (Fermentas Life Science) to conduct the restriction fragment length polymorphism analysis (RFLP) of RNA2 fragment of the SMoV isolates. The generated restriction patterns were analyzed by electrophoresis in $8 \%$ polyacrylamide gels in $1 \%$ TBE buffer.

The RT-PCR products were purified from the gels using QIAquick ${ }^{\circledR}$ Gel Extraction Kit (Qiagen, Poland) and sequenced in both strains using the same primers employed for amplification. The obtained sequences were aligned using ClustalW of the DNASTAR's Lasergene 7.1 software (DNASTAR Inc). The consensus sequences were compared with sequences available in GenBank using the BLAST algorithm (http://ncbi.nlm.nih.gov/BLAST/). The genetic relationships analysis of SMoV strains and the parallel RNA2 nucleotide sequences of the analogous SMoV sequences deposited at GenBank was carried out with the maximum likelihood method and subsequent bootstrap analysis in the MEGA software v. 5.2 (Tamura et al., 2007).

The presence of SMoV was confirmed in seven $F$. vesca var. semperflorens 'Alpine' indicator plants by RT-PCR using Smdetncr4a 5 and Sm2ncrlb 5 primers (Thompson and Jelkmann, 2003). For all the seven samples $\sim 1.3 \mathrm{~kb}$ products specific for partial RNA2 were also amplified when using primer pair 2SMoV1108F-2SMoV2386R (data not shown). The further study was aimed to evaluate of the possible genetic variability within this region of the seven

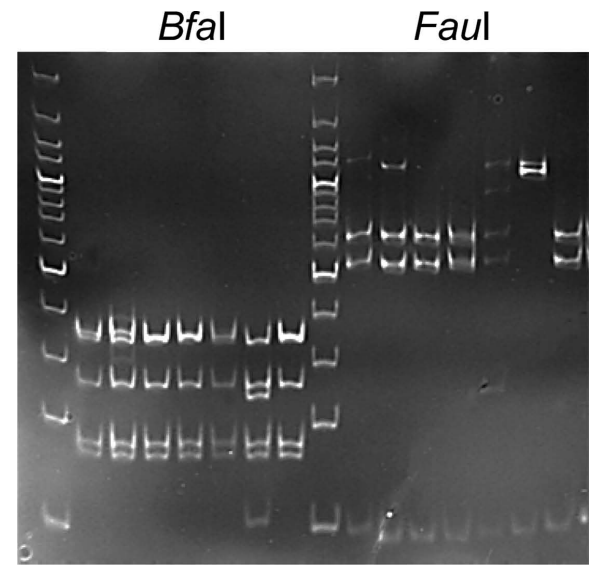

M 1234567 M 1234567

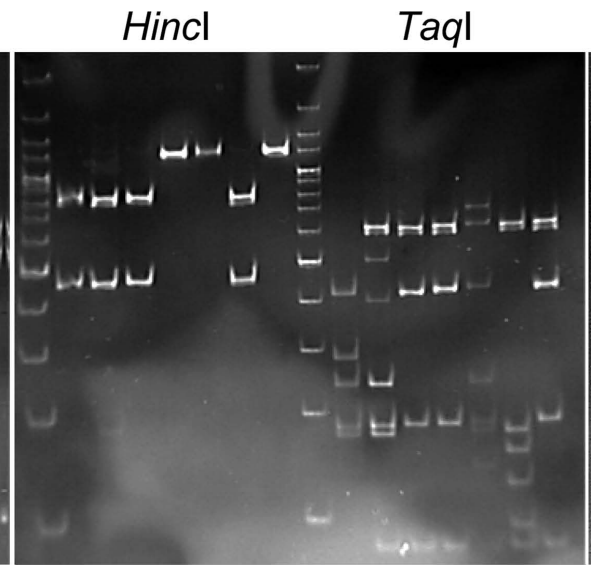

M 1234567 M 1234567

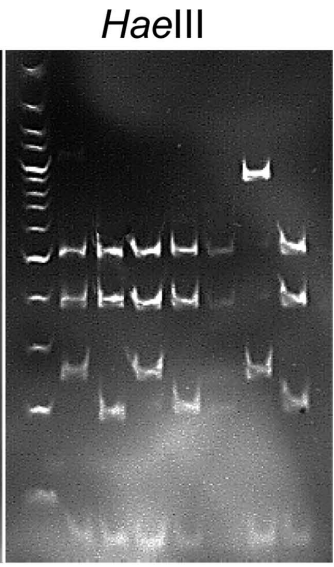

M 122344567

Fig. 1. Polyacrylamide gel showing the RFLP patterns of RNA2 fragment of the Strawberry mottle virus isolates amplified with 2SMoV1108F-2SMoV2386R primers digested with BfaI, FauI, HaeIII, HincI, and TaqI restriction enzymes of strawberry samples collected in 2015 in Bulgaria and Poland. Lanes: L - Thermo Scientific GeneRuler 100 bp Plus DNA Ladder, fragment sizes in base pairs (from top to bottom): 3000, 2000, 1500, 1200, 1000, 900, 800, 700, 600, 500, 400, 300, 200, 100. Samples: 1. Unkn-1108, 2. Granda-1108, 3. Markat-1108, 4. Pink-1108, 5. karkas-1108, 6. Pegat-1108, 7. Granat-1108. 
Table 1. Diversity of the RFLP profiles after digestion of RNA2 fragment of SMoV isolates by BfaI, FauI, HincI, TaqI, and HaeIII enzymes. Designation by A or B or C letters indicates the presence of different restriction patterns for the specific enzyme

\begin{tabular}{|c|c|c|c|c|c|c|}
\hline \multirow{2}{*}{ Isolate } & \multicolumn{5}{|c|}{ Restriction enzyme } & \multirow{2}{*}{ Profile } \\
\hline & $B f a \mathrm{I}$ & FauI & HincI & $T a q \mathrm{I}$ & HaeIII & \\
\hline Unkn-1108 & $\mathrm{A}$ & $\mathrm{A}$ & $\mathrm{A}$ & $\mathrm{A}$ & $\mathrm{A}$ & I \\
\hline Granda-1108 & A & B & A & B & B & II \\
\hline Markat-1108 & $\mathrm{B}$ & B & A & $\mathrm{C}$ & A & III \\
\hline Pink-1108 & B & B & B & $\mathrm{C}$ & B & IV \\
\hline karkas-1108 & B & B & B & B & B & $\mathrm{V}$ \\
\hline Pegat-1108 & $\mathrm{C}$ & $\mathrm{C}$ & A & $\mathrm{D}$ & $\mathrm{C}$ & VI \\
\hline Granat-1108 & $\mathrm{B}$ & $\mathrm{B}$ & $\mathrm{B}$ & $\mathrm{C}$ & $\mathrm{B}$ & IV \\
\hline
\end{tabular}

detected $\mathrm{SMoV}$ isolates.

The RFLP analysis showed a restriction fragment length polymorphism of the amplified RNA2 fragment of the seven virus isolates. Six different profiles were obtained after digestion of RT-PCR products with the enzymes $B f a \mathrm{I}$, FauI, HaeIII, HincI and TaqI. Only two isolates - Pink1108 and Granat-1108 showed the same restriction patterns for each of the separately used enzymes (Fig. 1, Table 1). This result indicated that when selecting the suitable restriction enzymes for digesting of the RNA2 fragment, the RFLP technique can be useful and reliable method for the study on genetic variability of SMoV strains.

The nucleotide sequences analysis of the partial RNA2, amplified using the primers designed during this study, confirmed the genetic diversity of the seven Polish SMoV isolates. The similarity of their nucleotide sequence within this region (1213 nt) was $94.7-100 \%$, with the greatest identity between Granat-1108 and Pink-1108 isolates. In turn, lowest nucleotide similarity (94.7\%) was found between Granda-1108 and Pegat-1108 isolates. Nucleotide sequences of the RNA2 fragment of the Pegat-1108, Markat-1108, karkas-1108 Granda-1108, Unkn-1108 and Granat-1108 isolates of SMoV were deposited in GenBank under accession numbers MH644000 - MH644005, respectively. The sequences of partial RNA2 of Pink-1108 and Granat-1108 isolates were identical thus only this one for Granat-1108 was submitted to the GenBank database.

A comparative analysis of the nucleotide sequences showed that the isolates found in Poland shared 91.3$92.1 \%$ identity with corresponding sequences of the $\mathrm{SMoV}$ strain '1134' from the Netherlands (GeneBank accession number: AJ311876), 75.7-99.2\% with the strains ' $\mathrm{SMoV}$ RNA2_A', 'SMoV_RNA2_B', and 'SMoV_RNA2_C' found in the Czech Republic (GeneBank accession numbers: MH013325, MH01326, and MH013327, respectively), and $82.1-93.2 \%$ with the sequences of Canadian strains 'Ontario', 'NB926', 'NSper3', 'Nsper17', and 'Nsper51'
(GeneBank accession numbers: KU177219, KU200454, KU200457, KU200459, and KU200461, respectively). Partial RNA2 sequence of the Czech strain 'SMoV_RNA2_C' showed the highest similarity with Polish isolates ranged from $96.1 \%$ for Pegat-1108 to $99.2 \%$ for Unkn-1108. In turn, surprisingly, the all seven Polish isolates showed the lowest similarity with the Czech strain 'SMoV_RNA2_A' ranging from $75.7 \%$ for Granat- 1108 isolate to $76.3 \%$ for Granda-1108 isolate.

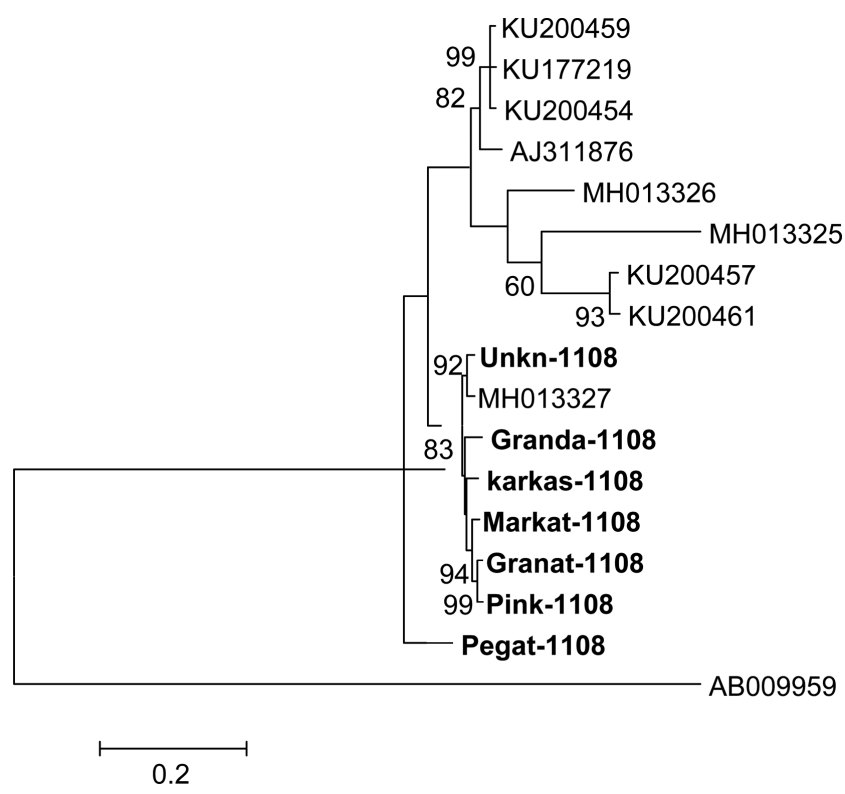

Fig. 2. Phylogenic analysis of the RNA2 fragment sequences of the $\mathrm{SMoV}$ isolates detected in Poland and nine representative SMoV strains. The SMoV isolates characterized during this study are indicated in bold. Phylogenetic tree was constructed by the maximum likelihood algorithm (MEGA 5.2) and the Kimura 3-parameter nucleotide substitution model in using 1,000 bootstrap replicates. Only bootstrap values higher than 60 are shown. The bar indicates the genetic distance as Kimura units. RNA2 sequence of Satsuma dwarf virus (GenBank accession number: AB009959) was used as the external group. 
Variability of the RNA2 sequence of the SMoV isolates from different geographic origin allowed to classify them into two main clusters (Fig. 2). One of them grouped the virus strains from Canada (KU177219, KU200454, KU200457, KU200459, KU200461), the Netherlands (AJ311876), and two strains from the Czech Republic (MH013325, MH013326). The other cluster included seven Polish isolates found in course of this study and the ' $\mathrm{SMoV}$ RNA2_C' strain from the Czech Republic (GeneBank accession number MH013327). However, only Unkn1108 isolate formed the distinct subgroup together with the Czech strain separately from the other Polish isolates. Common origin or spreading of the Czech strain ' $\mathrm{SMoV}$ RNA2_C' by aphids could explain its high genetic similarity to seven Polish isolates. Chaetosiphon sp. have not been found in Poland so far, but probably, due to climate changes these species of aphids have migrated from the warmer regions to our country spreading SMoV. Results of the phylogenetic analysis of amino acids sequences of the SMoV isolates were similar to these obtained in RNA2 nucleotide sequence analysis (data not shown).

This study has shown the presence of genetic diversity among seven Polish isolates of SMoV, and also has confirmed the variability within the strains identified in other countries. The high variability of the partial RNA2 among the Czech strains indicate that the occurrence of different $\mathrm{SMoV}$ isolates is not associated with geographical region. Although the newly designed primers allowed amplification of the RNA2 fragment of the all seven SMoV isolates, it is not sure that they would be suitable for the study of genetic variability of the all known and not identified so far virus isolates.

\section{Acknowledgments}

This work was performed in the frame of the multiannual programme "Actions to improve the competitiveness and innovation in the horticultural sector with regard to quality and food safety and environmental protection", financed by the Polish Ministry of Agriculture and Rural Development.

\section{References}

Babini, A. R., Cieślińska, M., Karešová, R., Thompson, J. R. and Cardoni, M. 2004. Occurrence and identification of strawberry viruses in five European countries. Acta Hort. 656:39-43.

Bhagwat, B., Dickison, V., Ding, X., Walker, M., Bernardy, M., Bouthillier, M., Creelman, A., DeYoung, R., Li, Y., Nie, X., Wang, A., Xiang, Y. and Sanfaçon, H. 2016. Genome sequence analysis of five Canadian isolates of strawberry mottle virus reveals extensive intra-species diversity and a longer
RNA2 with increased coding capacity compared to a previously characterized European isolate. Arch. Virol. 161:16571663.

Boom, R., Sol, C. J. A., Salimans, M. M. M., Jansen, C. L., Wertheim-van Dillen, P. M. E. and van der Noordaa, J. 1990. Rapid and simple method for purification of nucleic acids. $J$. Clin. Microbiol. 28:495-503.

Cieślińska, M. 2004. Detection of Strawberry mottle virus (SMoV) using RT-PCR - comparison of two RNA extraction methods. J. Fruit Ornam. Plant Res. 12:17-22.

Cieślińska, M. and Stankiene, J. 2005. The reaction of herbaceous plant species to infection with Strawberry mottle virus isolates occurring in Poland and Lithuania. Phytopathol. Pol. 37:91-97.

Cieślińska, M. and Zawadzka, B. 1991. Occurrence of virus diseases on strawberries in Poland. Phytopathol. Pol. 12:19-22.

Cieślińska, M. and Zawadzka, B. 1996. The spread of strawberry mottle virus and its effect on the yield of three strawberry cultivars. J. Fruit Ornam. Plant Res. 4:131-139.

Frazier, N. W. and Sylvester, E. S. 1960. Half-lives of transmissibility of two aphid-borne viruses. Virology 12:233-244.

Koloniuk, I., Fránová, J., Sarkisova, T. and Přibylová, J. 2018. Complete genome sequences of two divergent isolates of strawberry crinkle virus coinfecting a single strawberry plant. Arch. Virol. 163:2539-2542.

Malinowski, T. 1997. Silicacapture-reverse transcriptionpolymerase chain reaction (SC-RT-PCR): application for the detection of several plant viruses. In: Diagnosis and identification of plant pathogens, eds. by H. W. Dehne, G. Adam, M. Diekmann, J. Frahm, A. Mauler-Machnik, and P. van Halteren, pp. 445-448. Springer, Dordrecht, Netherlands.

Mellor, F. C. and Krczal, H. 1987. Strawberry mottle. In: Virus diseases of small fruits, ed. by R. H. Converse, pp. 10-16. USDA ARS Handbook No. 631, Washington, D.C., USA.

Sanfacon, H., Wellink, J., Le Gall, O., Karasev, A., van der Vlugt, R. and Wetzel, T. 2009. Secoviridae: a proposed family of plant viruses within the order Picornavirales that combines the families Sequiviridae and Comoviridae, the unassigned genera Cheravirus and Sadwavirus, and the proposed genus Torradovirus. Arch. Virol. 154:899-907.

Tamura, K., Dudley, J., Nei, M. and Kumar, S. 2007. MEGA4: Molecular evolutionary genetics analysis (MEGA) software version 4.0. Mol. Biol. Evol. 24:1596-1599.

Thompson, J. R., Leone, G., Lindner, J. L., Jelkmann, W. and Schoen, C. D. 2002. Characterization and complete nucleotide sequence of Strawberry mottle virus: a tentative member of a new family of bipartite plant picorna-like viruses. J. Gen. Virol. 83:229-239.

Thompson, J. R. and Jelkmann, W. 2003. The detection and variation of Strawberry mottle virus. Plant Dis. 87:385-390.

Thompson, J. R., Wetzel, S., Klerks, M. M., Vašková, D., Schoen, C. D., Špak, J. and Jelkmann, W. 2003. Multiplex RT-PCR detection of four aphid-borne strawberry viruses in Fragaria spp. in combination with a plant mRNA specific internal control. J. Virol. Methods 111:85-93. 